\title{
PENERAPAN PENGELOLAAN KELAS DALAM MENINGKATKAN HASIL BELAJAR PESERTA DIDIK PADA MATERI AKHLAK TERPUJI MATA PELAJARAN AQIDAH AKHLAK DI KELAS VIII MTS DDI SEPPANGE KABUPATEN BONE
}

\author{
St. Nur Alam ${ }^{1}$ St. Jumaeda ${ }^{2}$ \\ Guru MTs DDI Seppange \\ Nuralam.hannani@gmail.com
}

\begin{abstract}
This study aims to obtain data on improving learning outcomes and student activities as well as educators' abilities in classroom management. This research is Class Action Research (PTK) is a system study of learning practices in the classroom with the aim to improve and improve the quality of the learning process and learning outcomes of learners by performing certain actions. The Class Action Research Procedure (PTK) conducted in this study used two cycles gradually until the study was successful. Activities carried out in each cycle include Planning, Implementation, Observation, and Reflection. The research subjects numbered 35 students of grade VIII MTS DDI Seppange. Instruments used in the from of student worksheets and tests. The data is analyzed using descriptive analysis methods. The results showed that the application of classroom management can improve the learning outcomes of learners in the material of morally praiseworthy subjects in class VIII MTs DDI Seppange evidenced by the improvement of student learning outcomes in the initial test there were 2 (5.71\%) students have achieved a minal completion value with an average score of 52.75, at the end of the first test there were 19 learners or $54.35 \%$ have achieved a minal completion value with an average score of 65.71. While in the final test cycle II showed 35 learners or 100\% have achieved a minimum completion value, with an average score of 79.79 . The increase in students' learning outcomes from the initial test to cycle I was $12.96 \%$ and the increase in the learner's learning outcomes from cycle I to cycle II was $14.08 \%$.
\end{abstract}

Keywords: classroom management, improved learning outcomes

\begin{abstract}
Abstrak: Penelitian ini bertujuan untuk memperoleh data mengenai peningkatan hasil belajar dan aktivitas peserta didik serta kemampuan pendidik dalam pengelolan kelas. Penelitian ini adalah Penelitian Tindakan Kelas (PTK) merupakan suatu studi sistem terhadap praktik pembelajaran di kelas dengan tujuan untuk memperbaiki dan meningkatkan kualitas proses pembelajaran dan hasil belajar peserta didik dengan melakukan tindakan tertentu. Prosedur Penelitian Tindakan Kelas (PTK) yang dilakukan dalam penelitian ini menggunakan dua siklus secara bertahap sampai penelitian ini berhasil. Kegiatan yang dilakukan pada setiap siklus meliputi Perencanaan, Pelaksanaan, Pengamatan, dan Refleksi. Subyek penelitian berjumlah 35 siswa kelas VIII MTS DDI Seppange. Instrumen yang digunakan berupa lembar kerja peserta didik dan tes. Data dianalisis dengan menggunakan metode analisis deskriptif. Hasil Penelitian menunjukkan bahwa penerapan pengelolaan kelas dapat meningkatkan hasil belajar peserta didik pada materi akhlak terpuji mata pelajaran akidah akhlak di kelas VIII MTs DDI Seppange dibuktikan dengan peningkatan hasil belajar peserta didik pada tes awal terdapat 2 (
\end{abstract}


$5,71 \%$ ) peserta didik telah mencapai nilai ketuntasan minal dengan nilai rata-rata sebesar 52,75, pada tes akhir siklus I terdapat 19 peserta didik atau 54,35\% telah mencapai nilai ketuntasan minal dengan nilai rata-rata sebesar 65,71 . Sedangkan pada tes akhir siklus II menunjukan 35 peserta didik atau 100\% telah mencapai nilai ketuntasan minimal, dengan nilai rata-rata sebesar 79,79. Peningkatan hasil belajar peserta didik dari tes awal ke siklus I sebesar 12,96\% dan peningkatan hasil belajar peserta didik dari siklus I ke siklus II sebesar 14,08\%.

Kata kunci: Pengelolaan Kelas, Peningkatan hasil Belajar.

\section{PENDAHULUAN}

Perubahan zaman yang dinamis dalam segala aspek kehidupan harus diimbangi dengan pengembangan kreativitas sumber daya manusia yang memadai. Untuk menyiapkan sumber daya manusia tersebut, sistem pendidikan di Indonesia harus disempurnakan sesuai dengan tututan perubahan. Untuk mencapai tujuan tersebut pemerintah telah mengeluarkan berbagai peraturan perundangan dan kebijakan, diantaranya tentang standar kualifikasi Akademik dan kompetensi guru yang harus dikembangkan secara utuh dari empat kompetensi utama, yaitu kompetensi pedagogik, kepribadian, sosial, dan profesional.(Jumaeda, 2015:163)

Berbagai upaya dalam peningkatan kualitas sumber daya manusia di Indonesia telah dilakukan oleh pemerintah diantaranya dengan melalui pelaksanaan pendidikan, namun praktek pendidikan di Indonesia selama ini kurang mampu menghasilkan sumber daya manusia yang memiliki keunggulan kompetitif di dunia persaingan global. Menyadari rendahnya mutu dan kualitas pendidikan sebagai salah satu penyebab lemahnya kualitas sumber daya manusia dalam mendukung pembangunan nasional, maka pemerintah telah melakukan berbagai upaya dalam usaha peningkatan kualitas sumber daya manusia. Upaya tersebut diantaranya dengan melalui lembaga pendidikan, yang sekaligus disertai dengan peningkatkan mutu dan kualitas pendidikan itu sendiri.(St Jumaeda, 2018)

Guru merupakan salah satu faktor yang sangat penting dalam meningkatkan kualitas pendidikan, selain memiliki peran mentransfer ilmu, guru juga mempunyai peran dalam membantu proses internalisasi moral kepada peserta didik. Karena itu guru harus memiliki bekal berupa persiapan diri untuk menguasai sejumlah pengetahuan, ketrampilan, dan kemampuan khusus sebagai kompetensi dasar yang terkait dengan profesi keguruannya agar ia dapat menjalankan tugasnya dengan 
baik serta dapat memenuhi kebutuhan dan harapan peserta didiknya.(Nur Khozin, 2018)

Guru tidak cukup hanya menyampaikan materi pengetahuan kepada peserta didik di kelas, namun dibutuhkannya kemampuan untuk mendapatkan dan mengelola informasi yang sesuai dengan kebutuhan profesinya. Mengajar bukan hanya usaha untuk menyampaikan ilmu pengetahuan, melainkan juga usaha menciptakan sistem lingkungan yang membelajarkan peserta didik agar tujuan pembelajaran dapat tercapai secara optimal. Mengajar dalam pemahaman seperti ini memerlukan suatu teknik pengelolaan yang tepat bagi tujuan yang ingin dicapai, terutama dalam upaya mengembangkan kreativitas dan sikap subjek didik. Untuk itu, perlu dibina dan dikembangkan kemampuan profesional guru untuk mengelola program pengajaran dengan pengelolaan kelas yang kaya dengan variasi.(Gulo, 2002:1)

Pengelolaan kelas mengandung seperangkat keterampilan penting yang saling terkait, tetapi juga terjalin erat dengan keterampilan-keterampilan profesional lainnya, oleh karena tanpa kemampuan dalam pengelolaan kelas guru-guru tidak dapat memanfaatkan sepenuhnya keterampilan-keterampilan lain yang dimilikinya. Dalam konteks ini, pengelolaan kelas dapat dianggap sebagai suatu variabel ambang pintu (threshold variable), semacam pintu masuk untuk suksesnya pembelajaran, karena itu guru perlu memiliki keterampilan yang cukup memadai dalam mengorganisasi agar semua kemampuan profesionalnya yang lain dapat berkembang. (Wragg, 1997:28)

Peningkatan kualitas pembelajaran akan sangat ditentukan oleh kesiapan sekolah dalam hal ketersediaan fasilitas penunjang kegiatan pembelajaran, profesionalisme guru dalam melaksanakan program pembelajaran, iklim akademik terkait situasi yang muncul akibat interaksi antara guru dan peserta didik atau intraksi antar-peserta didik, dan motivasi belajar peserta didik. Untuk meningkatkan kualitas pembelajaran di sekolah/madrasah terdapat tiga komponen utama program pembelajaran. Ketiga komponen ini saling terkait, yaitu (1) perencanaan pembelajaran dirancang secara terencana untuk menjamin terlaksananya proses pembelajaran yang efektif dan benar yaitu, (2) pelaksanaan proses pembelajaran, dan penilaian.(St. Jumaeda, 2018:56)

Penilaian pembelajaran pada dasarnya merupakan upaya memperoleh informasi secara komprehensif mengenai kekuatan, kelemahan dan kemajuan 
belajar peserta didik yang meliputi aspek kognitif, afektif, dan psikomotor. Aspek kognitif dapat berupa konsep, prinsip, teori, dan hukum alam yang merupakan hasil telaah produk dari proses ilmiah para ahli. Aspek psikomotor dapat berupa keterampilan mengamati, menghitung, mengklasifikasi, mengukur, memprediksi dan mengkomuniksikan hasil. Aspek Aspek afektif dapat berupa nilai-nilai dan sikap ilmiah seperti sikap objektif berpikir bebas, tidak berprasangka, dan disiplin.(Jumaeda, 2020)

Aktifitas belajar bagi setiap peserta didik tidak selamanya dapat berlangsung secara wajar, ada peserta didik dengan cepat menangkap apa yang dipelajari, ada yang lambat. Perbedaan individu ini pula penyebab perbedaan tingkah laku pada setiap peserta didik yang menimbulkan persoalan yang muncul pada saat proses pembelajaran di kelas, yang kadang-kadang tidak dapat diatasi guru dengan baik. Fenomena terjadi disebabkan guru tidak mampu mengelola kelas dengan baik dan kurang mengevaluasi proses pembelajarannya di kelas. Dampaknya peserta didik tidak dapat belajar dengan baik, merasa jenuh, bosan bahkan membuat ulah dan bikin gaduh. Untuk itu Seorang guru benar-benar dituntut agar dapat menggunakan keterampilan pengelolaan kelas dengan baik. Selain itu guru selalu mawas diri dalam usaha dan tindakannya, tidak lekas puas dengan apa yang telah dicapainya, selalu mengadakan koreksi diri dan intropeksi demi perbaikan dan penyempurnaan pembelajaran di sekolah, sebab gurulah yang memikul tanggung jawab atas keberhasilan pembelajaran dan kegagalan peserta didik di sekolah.

MTs DDI Seppange merupakan sebuah lembaga pendidikan menengah pertama yang berada di bawah naungan Kementerian Agama. Sebagai sebuah lembaga pendidikan keagamaan tentunya mata pelajaran akidah ahlak merupakan salah satu mata pelajaran yang diajarkan. Dalam pelaksanaan pembelajaran guru telah menerapkan berbagai metode, strategi dan sistem pembelajaran, untuk dapat menentukan hakikat pembelajaran yang sebenarnya, dengan menciptakan efesiensi pembelajaran dalam mencapai hasil belajar peserta didik yang optimal.(Jumaeda, 2017)

Berbagai upaya telah dilakukan dalam usaha mencapai peningkatan kualitas proses dan kualitas output pembelajaran yang dilaksanakan di MTs DDI Seppange. Peningkatan kualitas proses dan kualitas output pembelajaran ditentukan oleh tiga unsur, yaitu: guru, peserta didik, dan kurikulum. Ketiga unsur tersebut dapat diasumsikan bahwa (1) Guru, sesuai dengan fungsinya bertugas mengoptimalkan 
kemampuan peserta didik dalam belajar. Dalam mengoptimalkan kemampuan peserta didik, profesionalisme guru yang memadai dalam mengajar sangat menentukan peningkatan kualitas pembelajaran sekaligus keberhasilan program pembelajaran untuk mencapai tujuan sebagaimana telah direncanakan di dalam RPP yang telah disusun sebelumnya, (2 telah disusun sebelumnya, (2) Peserta didik, dengan segala karakteristiknya dalam proses pembelajaran diharapkan secara maksimal dapat mencapai tujuan belajar. (3) Kurikulum, adalah merupakan pedoman atau media serta sekaligus merupakan salah satu fasilitas penunjuang untuk mencapai tujuan yang diinginkan.(St Jumaeda, 2018).

Peningkatan hasil belajar peserta didik sangat memungkinkan dapat meningkat dengan pengelolaan kelas yang tepat. Pengelolaan kelas yang tepat dan efektif mengakibatkan peserta didik akan lebih termotivasi untuk lebih giat dalam meningkatkan belajarnya, sehingga ketuntasan materi dan hasil belajar yang dicapai lebih meningkat. Terkait dengan hal tersebut, di MTs DDI Seppange berdasarkan pengalaman peneliti secara empiris khususnya mata pelajaran akidah ahlak terlihat guru belum memaksimalkan pengelolaan kelas secara tepat dan efektif dalam pembelajaran sehingga hasil belajar peserta didik tidak memenuhi KKM mata pelajaran yang telah ditetapkan. Berdasarkan hal tersebut penulis tertarik untuk mencari solusi yang tepat dalam mengatasi masalah rendahnya hasil belajar peserta didik khususnya pada mata pelajaran akidah ahlak materi ahlak terpuji. Salah satu solusi yang praktis adalah dengan melakukan penelitian tindakan kelas (PTK) melalui penerapan pengelolaan kelas untuk meningkatkan hasil belajar peserta didik,

\section{METODE}

Jenis penelitian yang digunakan adalah Penelitian Tindakan Kelas (PTK). Penelitian Tindakan Kelas merupakan suatu pencermatan terhadap kegiatan belajar berupa sebuah tindakan, yang sengaja dimunculkan dan terjadi dalam sebuah kelas secara bersama. Tindakan tersebut diberikan oleh pendidik atau dengan arahan dari pendidik yang dilakukan oleh peserta didik (Arikunto dkk, 2009: 3). PTK adalah studi sistem terhadap praktik pembelajaran di kelas dengan tujuan untuk memperbaiki dan meningkatkan kualitas proses pembelajaran dan hasil belajar peserta didik dengan melakukan tindakan tertentu. Langkah penelitian Tindakan Kelas (PTK) pada penelitian ini dapat digambarkan sebagai berikut: 


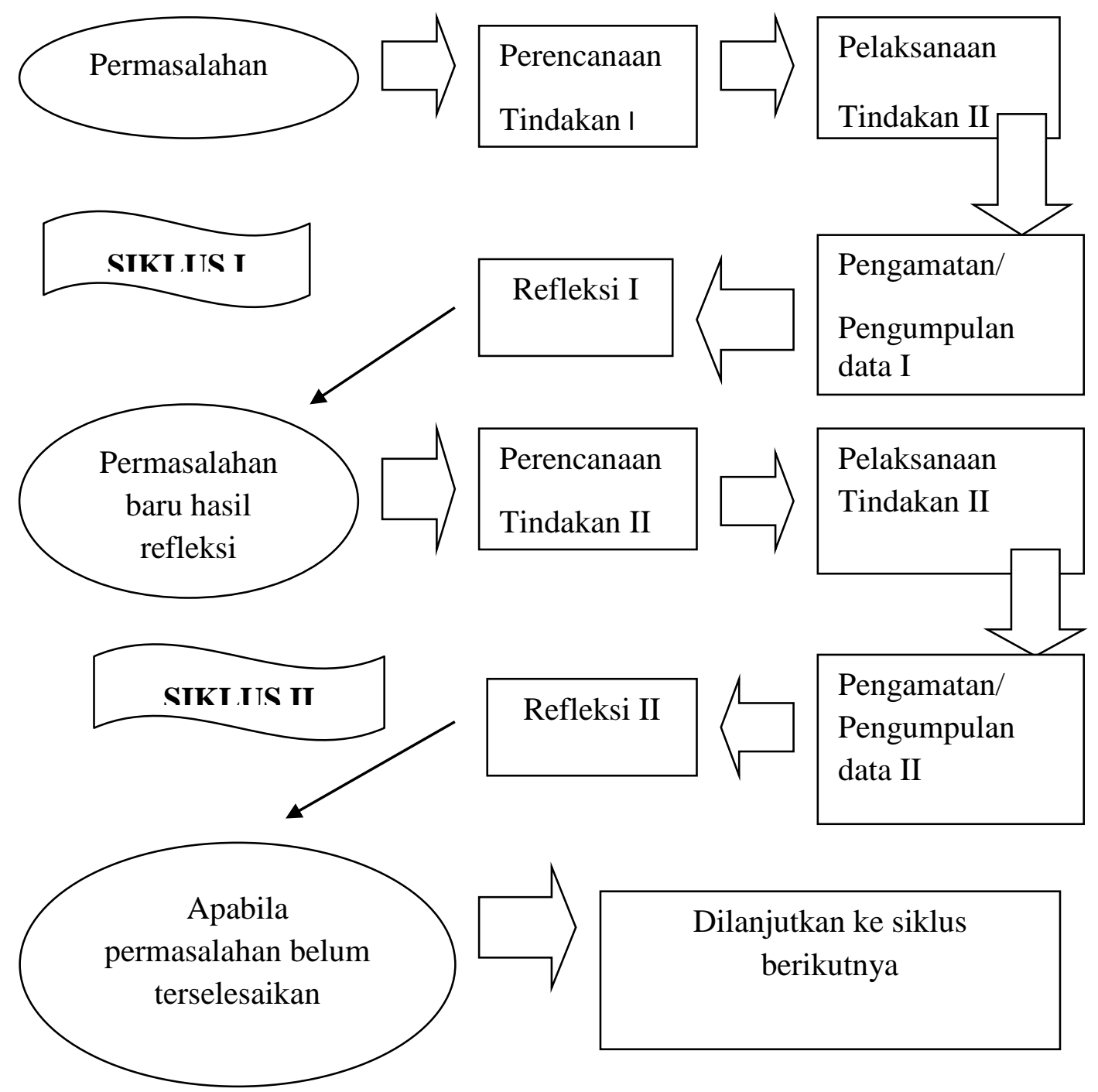

Gambar 1. Langkah Penelitian PTK

Prosedur Penelitian Tindakan Kelas (PTK) yang dilakukan dalam penelitian ini menggunakan dua siklus secara bertahap sampai penelitian ini berhasil. Kegiatan yang dilakukan pada setiap siklus meliputi Perencanaan Tidakan, Pelaksanaan Tindakan, Pengamatan Tindakan, dan Refleksi.

\section{Siklus I}

\section{a. Perencanaan}

Pada tahap ini, peneliti menyiapkan Rancangan Pelaksanaan Pembelajaran (RPP) dan merencanakan pembelajaran dengan menggunakan teknik pengelolaan kelas pada materi akhlak terpuji. 


\section{b. Pelakasanaan}

Menjelaskan materi akhlak terpuji dengan menggunakan Rencana Pelaksanaan Pembelajaran (RPP) serta teknik pengelolahan kelas yang sudah dikuasai dan diakhiri dengan melakukan tes sebagai evaluasi dari materi-materi yang disampaikan.

\section{c. Pengamatan}

Melakukan pengamatan (observasi), dengan menggunakan lembar observasi guru, peserta didik dan kemampuan peserta didik dalam menangkap dan memahami pelajaran yang disampaikan serta menjawab pertanyaan-pertanyaan yang diberikan oleh guru dalam bentuk soal baik secara lisan maupun tulisan kemudian datanya diambil oleh peneliti sebagai data yang akan diolah.

\section{d. Refleksi}

Setelah pengamatan selesai dilakukan, kemudian peneliti, kolaborator dan teman sejawat secara Bersama-sama mengkaji kembali hasil pengamatan tindakan kelas yang telah dilaksanakan pada saat proses belajar mengajar yang didapatkan pada setiap siklus. Kekurangan yang terdapat pada siklus direcanakan lagi untuk dilakukan perbaikan pada siklus II.

\section{Siklus I}

Pada siklus II dirancang sama halnya dengan siklus I dengan materi akhlak terpuji. Langkah-langkah yang dilakukan sama seperti pada siklus I, hanya dalam siklus II, hal-hal yang dianggap masih kurang dalam siklus I akan diperbaiki pada siklus II.

Subyek penelitian adalah peserta didik kelas VIII yang berjumlah 35 peserta didik tahun ajaran 2019/2020. Instrumen yang digunakan dalam pengumpulan data ini berupa lembar kerja peserta didik yang berguna untuk mencatat dokumen atas hasil kerja peserta didik, dan tes untuk mengetahui hasil belajar peserta didik. Lembar Observasi yang memuat panduan mengobservasi aktivitas peserta didik di kelas ketika proses pembelajaran berlansung. Sedangkan lembar observasi pendidik digunakan untuk mengetahui kemampuan pendidik. Sedangkan Rencana Pelaksanaan Pembelajaran (RPP) berfungsi sebagai acuan dalam melaksanakan tindakan-tindakan selama proses pembelajaran.

Data dianalisis dengan menggunakan metode analisis deskriptif. Dengan melihat skor yang diperoleh oleh setiap peserta didik setiap kali diadakan tes. Tes awal (pree test) dilihat perkembangannya dengan membandingkan dengan siklus I, apakah ada peningkatan atau tidak. Demikian juga diadakan perbandingan antara 
tes awal dengan tes pada siklus II untuk melihat peningkatan hasilnya. Analisis dilakukan dengan menggunakan rumus:

\section{Peningkatan Prestasi}

a. Peningkatan setelah siklus $\mathrm{I}=\mathrm{R}$ siklus I $-\mathrm{R}$ Tes awal

b. Peningkatan setelah Siklus II = R siklus II - R siklus I

Total = Peningkatan Siklus I + Peningkatan Siklus II

$$
\begin{aligned}
& =\mathrm{X} 1 \\
& =\frac{X 1}{R-\text { rataTes awal }} \times 100 \% \\
& =\mathrm{X} 2 \%
\end{aligned}
$$

\section{HASIL}

Berdasarkan hasil evaluasi belajar peserta didik pada pree-test (tes awal) menunjukkan $2(5,71 \%)$ peserta didik telah mencapai kriteria ketuntasan minal yang ditetapkan yaitu 70 dan 33 (94,71\%) peserta didik yang belum memenuhi kriteri ketuntasan minimal (KKM) dengan rata-rata nilai yang dicapai sebesar 52,75.

\section{Siklus I}

\section{1). Perencanaan}

a. Menganilis kompetensi dasar yang akan disampaikan kepada peserta didik dengan menggunakan penerapan pengelolaan kelas

b. Menyiapkan RPP

c. Menyiapkan Lembar kerja peserta didik

d. Menyiapkan instrument yang akan digunakan dalam siklus PTK

e. Menyiapkan sumber belajar yang akan digunakan dalam proses pembelajaran

Siklus I dilaksanakan dengan satu kali pertemuan yang dihadiri oleh 35 peserta didik dan kolaborator serta teman sejawat yang masing-masing berjumlah 1 orang. 


\section{2). Pelaksanaan}

a. Sebagian peserta didik masih menimbulkan masalah sehubungan dengan perilaku mereka pada saat proses pembelajaran berlangsung.

b. Sebagian peserta didik belum dapat menangkap dan memahami materi pembelajaran yang diberikan guru (Peneliti) secara utuh dan menyeluruh.

Untuk mengatasi masalah di atas dilakukan upaya sebagai berikut:

a. Guru menerapkan langkah-langkah pengelolaan kelas untuk menyelesaikan masalah yang dihadapi sehubungan dengan perilaku pesrta didik selama proses pembelajaran berlangsung.

b. Guru membantu pesrta didik yang belum memahami materi yang disampaikan sehingga peserta didik dapat memahami materi tersebut.

Pada akhir siklus pertama I dari hasil pengamatan kolabolator dan teman sejawat dapat disimpulkan:

a. Peserta didik mulai dapat memahami materi yang diajarkan.

b. Peserta didik mulai berpartisipasi dalam proses pembelajaran.

c. Peserta didik mampu menyimpulkan materi yang diajarakan.

Pada tahap pelaksanaan proses pembelajaran berlangsung berdasarkan rencana pelaksanan pembelajaran (RPP). Proses ini diawali dengan kegiatan pendahuluan, kegiatan inti dan kegiatan penutup yang digunakan untuk menyimpulkan materi yang telah disampaikan dan mengukur hasil belajar peserta didik dengan dilakukan pos test.

\section{3). Pengamataan}

Selama proses pembelajaran berlangsung peneliti, kolaborator dan teman sejawat melakukan penilaian proses dan pengamatan terhadap hasil belajar peserta didik dengan menggunakan lembar observasi yang telah disediakan.

\section{4). Refleksi}

Berdasarkan data hasil pengamatan terhadap pelaksanaan proses pembelajaran pada siklus I terdapat temuan-temuan sebagai berikut:

Hasil belajar peserta didik yang masih tergolong rendah, karena sebagian peserta didik masih menimbulkan masalah pada saat proses pembelajaran sehingga sebagian peserta didik lainnya belum dapat menangkap dan memahami apa yang disampaikan oleh guru.

Berdasarkan siklus I menunjukan 19 peserta didik atau 54,35\% telah mencapai nilai ketuntasan minimal (KKM) yang telah ditetapkan dan 16 peserta didik 
atau $45,65 \%$ belum mencapai nilai ketuntasan (KKM). Rata-rata hasil belajar yang dicapai peserta didik pada siklus I sebesar 65,71. Untuk memperbaiki kekurangankekurangan tersebut, maka dilakukanlah replanning dan diperbaiki pelaksanaanya untuk dilanjutkan ke siklus II.

\section{Siklus II}

Berdasarkan hasil refleksi pada siklus I maka dilakukanlah perencanaan tindakan pada siklus II. Seperti halnya pada siklus I, siklus II ini terdiri dari perencanaan, pelaksanaan, pengamatan dan refleksi.

\section{1). Perencanaan}

a. Merencanakan perbaikan dari kekurangan yang dilakukan pada siklus I berdasarkan hasil refleksi pada siklus I untuk dilakukan pada siklus II

b. Memberikan motivasi kepada peserta didik agar lebih aktif lagi dalam pembelajaran.

c. Lebih intensif lagi membimbing peserta didik yang mengalami kesulitan belajar.

d. Memberi pengakuan atau penghargaan kepada peserta didik.

Siklus II dilaksanakan setelah siklus I dengan jumlah peserta didik yang sama yaitu 35 orang serta dihadiri juga oleh kolabolator dan teman sejawat seperti yang diterapkan pada siklus I.

\section{2). Pelaksanaan}

a. Suasana pembelajaran sudah lebih mengarah kepada materi yang disampaikan karena dilengkapi dengan metode tanya jawab, ceramah dan tutor sebaya, dengan membagi peserta didik menjadi beberapa kelompok.

b. Memberi penjelasan teknis tentang alur pembelajaran.

c. Tiap kelompok diberikan materi yang harus dibahas.

a. Selama kerja atau diskusi kelompok, guru melakukan penilaian dan bimbingan seperlunya.

b. Perwakilan peserta didik dari kelompok yang sudah siap, mempresentasikan hasil kerja kelompoknya, dan peserta didik lain memberikan tanggapan.

c. Penguatan dan menyimpulkan materi dilakukan secara bersama-sama.

Proses pelakasanan pada siklus II ini lebih meningkatakan hasil belajar peserta didik karena suasana pembelajaran yang efektif dan menyenangkan 
sudah mulai tercipta. Sehingga peserta didik merasa lebih termotivasi untuk bertanya dan menanggapi presentasi diskusi dari kelompok lain.

\section{3). Pengamatan}

Selama proses pembelajaran berlangsung peneliti, kolaborator dan teman sejawat melakukan penilaian proses dan pengamatan terhadap hasil belajar peserta didik dengan menggunakan lembar observasi yang telah disediakan

\section{4). Refleksi}

Setelah tahap perencanaan, pelaksanaan dan pengamatan, peneliti dan kolabolator serta teman sejawat mengadakan refleksi terkait hasil belajar yang diproleh peserta didik Adapun keberhasilan-keberhasilan yang diperoleh dalam siklus II ini adalah sebagai berikut:

a. Meningkatnya aktivitas belajar peserta didik dalam proses pembelajaran. Hal ini didukung oleh terciptanya suasana pembelajaran yang efektif dan menyenangkan.

b. Meningkatnya hasil belajar peserta didik dengan menggunakan penerapan pengeloaan kelas.

Berdasarkan hasil pemerikasan tes akhir siklus II dengan penerapan pengelolaan kelas diketahui terdapat peningkatan hasil belajar peserta didik. Hasil tes belajar peserta didik pada siklus II menunjukan semua peserta didik yang berjumlah 35 (100\%) peserta didik telah mencapai nilai ketuntasan minimal (KKM) dalam mengikuti proses pembelajaran dengan menggunakan penerapan pengelolaan kelas., dengan nilai rata-rata sebesar 79,79. Hasil tes akhir siklus II menunjukan adanya peningkatan hasil belajar peserta didik dengan menggunakan penerapan pengelolaan kelas pada materi akhlak terpuji mata pelajaran aqidah akhlak di kelas VIII MTs DDI Seppange. Dengan pertimbangan terhadap hasil belajar peserta didik yang telah mencapai nilai ketuntasan minimal secara keseluruhan dari 35 peserta didik, maka peneliti, kolabolator dan teman sejawat bersepakat untuk tidak dilanjutkan pada siklus berikutnya.

\section{PEMBAHASAN}

Guru sebagai manajer dalam kegiatan pembelajaran dikelas memiliki peran penting dalam meningkatkan hasil belajar peserta didik. Sebagai tenaga profesional, guru dituntut tidak hanya mampu mengelola pembelajaran saja tetapi juga harus 
mampu mengelola kelas, dengan menciptakan dan mempertahankan kondisi belajar yang optimal bagi tercapainya tujuan pembelajaran. Peningkatan mutu pendidikan akan tercapai apabila proses pembelajaran yang diselenggarakan di dalam kelas benar-benar tepat dan efektif serta berguna bagi tercapainya kemampuan kognitif, afektif dan psikomotorik pesrta didik. Karena itu guru dituntut untuk meningkatkan peran dan kompetensinya, sebab guru yang berkompeten akan lebih mampu menciptakan lingkungan belajar yang, nyama dan efektif serta lebih mampu melakukan pengelolaan kelas secara tepat sesuai dengan kondisi dan karakteristik peserta didik, sehinggga hasil belajar peserta didik dapat meningkat secara optimal.

Pengolaan kelas sangat penting bagi seorang guru dalam perencanaan dan pelaksanakan pembelajaran bagi peserta didik, sebab dengan pengolahan kelas yang tepat disatu sisi memudahkan guru dalam melaksanakan proses pembelajaran, dan disisi lain dapat memudahkan para peserta didik menyerap materi pelajaran yang disampaikan guru. Berhasil tidaknya suatu pengelolaan kelas oleh seorang guru tergantung pada cara guru dalam mendesain strategi pembelajaran.(Sabri, 2005:2)

Peningkatan kualitas pembelajaran dapat dilihat dari segi proses maupun dari segi hasil, dari segi proses pembelajaran dikatakan berhasil dan berkualitas apabila seluruhnya atau setidak-tidaknya sebagian besar peserta didik terlibat secara aktif baik fisik, maupun mental dalam proses pembelajaran, disamping meningkatan kegairahan belajar yang tinggi, semangat belajar yang besar dan rasa percaya diri, peserta didik. Sementara dari segi hasil, proses pembelajaran yang dikatakan berhasil apabila terjadi perubahan perilaku yang positif dari diri peserta didik dan didukung dari hasil belajar peserta didik yang lebih baik secara keseluruhan atau Sebagian besar peserta didik telah memperoleh hasil belajar yang optimal.setidaktidaknya sebagian besar.(Muslika, 2010: 128)

Penerapan pengelolaan kelas pada materi akhlak terpuji mata pelajaran akidah akhlak di kelas VIII MTs DDI Seppange dapat meningkatkan hasil belajar peserta didik yang dapat dibuktikan dengan peningkatan hasil belajar peserta didik dari tes awal memperoleh nilai rata-rata sebesar 52,75. Sementara pada siklus I memperoleh nilai rata-rata sebesar 65,71 dan pada siklus II hasil belajar peserta didik memperoleh nilai rata-rata sebesar 79,79.

Berdasarkan dari evaluasi hasil belajar peserta didik dari tes awal hingga siklus II menunjukkan bahwa penerapan pengelolaan kelas dapat meningkatkan 
kualitas pembelajaran baik dari segi proses maupun dari segi hasil, hal ini dibuktikan dengan peningkatan hasil belajar peserta didik dari tes awal ke siklus I sebesar $12,96 \%$ dan peningkatan hasil belajar peserta didik dari siklus I ke siklus II sebesar $14,08 \%$.

\section{KESIMPULAN}

Penerapan pengelolaan kelas dapat meningkatkan hasil belajar peserta didik pada materi akhlak terpuji mata pelajaran akidah akhlak di kelas VIII MTs DDI Seppange Hal ini dibuktikan dari hasil tes awal peserta didik terdapat 2 ( 5,71\%) peserta didik telah mencapai nilai ketuntasan minal dengan nilai rata-rata sebesar 52,75 . Sementara pada tes akhir siklus I terdapat 19 peserta didik atau 54,35\% telah mencapai nilai ketuntasan minal dengan nilai rata-rata sebesar 65,71. Sedangkan pada tes akhir siklus II menunjukan 35 peserta didik atau 100\% telah mencapai nilai ketuntasan minimal, dengan nilai rata-rata sebesar 79,79. Peningkatan hasil belajar peserta didik dari tes awal ke siklus I sebesar $12,96 \%$ dan peningkatan hasil belajar peserta didik dari siklus I ke siklus II sebesar 14,08\%. Hal ini menunjukkan bahwa penerapan pengelolaan kelas dapat meningkatkan kualitas pembelajaran baik dari segi proses maupun dari segi hasil pembelajaran.

\section{DAFTAR PUSTAKA}

[1] Arikunto, S. dkk. (2009). Penelitian Tindakan Kelas. Jakarta: PT Bumi Aksara.

[2] Gulo, W.Strategi Belajar Mengajar (2002) Jakarta: PT. Gramedia Widiasarna Indonesia.

[3] Jumaeda, S. (2015) 'Kreativitas dalam Pedagogik: Thinking and Creativity of Teacher', Jurnal Harison Pendidikan, 10(2), pp. 163-174.

[4] Jumaeda, S. (2017) 'Hubungan Sistem Pembelajaran Modul Terhadap Hasil Belajar Peserta Didik Pada Mata Pelajaran Bahasa Arab Di MTs DDI Seppange', al-Iltizam: Jurnal Pendidikan Agama Islam 2(2).

[5] Jumaeda, St (2018) 'Evaluation Implementation of Curriculum Unit Level of Education for Arabic Lenguage Learning in Mts DDI Seppange', al-lltizam: Jurnal Pendidikan Agama Islam, 3(2), p. 90. doi: 10.33477/alt.v3i2.599. 
[6] Jumaeda, St. (2018) 'Implementasi Standar Penilaian Dalam Pembelajaran PAI pada kurikulum 2013', al-Iltizam Jurnal Pendidikan Agama Islam 3(1), pp. 5363.

[7] Jumaeda, S. (2020) 'Evaluasi Pelaksanaan Classroom Assesment di Madrasah Madrasah Tsanawiyah DDI Seppange Kecamatan Bengo Kabupaten Bone', AlIltizam: Jurnal Pendidikan Agama Islam 5(2), pp. 66-79.

[8] Muslika, (2010). Sukses Profesi Guru dengan Penelitian Tindakan Kelas, Yogyakarta: Interprebook, .

[9] Nur Khozin, S. J. L. R. (2018) 'Pemberdayaan Guru Pendidikan Agama Islam Melalui Peningkatan Kompetensi Guru Pada Tingkat Sekolah Dasar Di Waimital', al-Iltizam: Jurnal Pendidikan Agama Islam, 3(1), p. 28. doi: 10.33477/alt.v3i1.415.

[10] Sabri, Ahmad. (2005) Strategi Belajar Mengjar dan Micro Teaching, Jakarta: Quantum Teaching.

[11] Wragg, E.C. (1997) Keterampilan Mengajar Di Sekolah Dasar. Jakarta: PT. Gramedia Widiasarna Indonesi. 